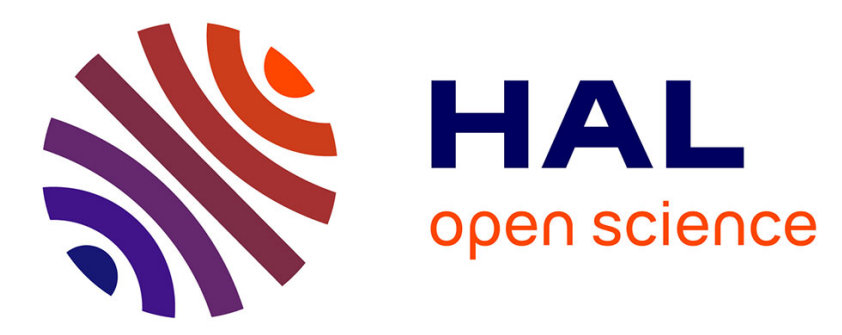

\title{
Structural and Biological Assessment of Zinc Doped Hydroxyapatite Nanoparticles
}

\author{
Cristina Liana Popa, Aurélien Deniaud, Isabelle Michaud-Soret, Régis \\ Guégan, Mikael Motelica-Heino, Daniela Predoi
}

\section{- To cite this version:}

Cristina Liana Popa, Aurélien Deniaud, Isabelle Michaud-Soret, Régis Guégan, Mikael Motelica-Heino, et al.. Structural and Biological Assessment of Zinc Doped Hydroxyapatite Nanoparticles. Journal of Nanomaterials, 2016, 9, pp.399 - 10. 10.1155/2016/1062878 . insu-01414519

\section{HAL Id: insu-01414519 https://hal-insu.archives-ouvertes.fr/insu-01414519}

Submitted on 12 Dec 2016

HAL is a multi-disciplinary open access archive for the deposit and dissemination of scientific research documents, whether they are published or not. The documents may come from teaching and research institutions in France or abroad, or from public or private research centers.
L'archive ouverte pluridisciplinaire HAL, est destinée au dépôt et à la diffusion de documents scientifiques de niveau recherche, publiés ou non, émanant des établissements d'enseignement et de recherche français ou étrangers, des laboratoires publics ou privés. 


\title{
Structural and Biological Assessment of Zinc Doped Hydroxyapatite Nanoparticles
}

\author{
Cristina Liana Popa, ${ }^{1}$ Aurélien Deniaud, ${ }^{2,3,4}$ Isabelle Michaud-Soret, ${ }^{2,3,4}$ Régis Guégan, ${ }^{5}$ \\ Mikael Motelica-Heino, ${ }^{5}$ and Daniela Predoi ${ }^{1}$ \\ ${ }^{1}$ National Institute of Materials Physics, P.O. Box MG 07, 07725 Magurele, Romania \\ ${ }^{2}$ CNRS, Laboratoire de Chimie et Biologie des Métaux (LCBM), UMR 5249, CNRS-CEA-UJF, 38054 Grenoble, France \\ ${ }^{3}$ CEA, LCBM, 38054 Grenoble, France \\ ${ }^{4}$ University Grenoble Alpes, LCBM, 38054 Grenoble, France \\ ${ }^{5}$ ISTO, UMR 7327, CNRS, Université d'Orléans, 1 A rue de la Férollerie, 45071 Orléans Cedex 2, France
}

Correspondence should be addressed to Daniela Predoi; dpredoi@gmail.com

Received 29 March 2016; Revised 23 May 2016; Accepted 1 June 2016

Academic Editor: Antonios Kelarakis

Copyright (C) 2016 Cristina Liana Popa et al. This is an open access article distributed under the Creative Commons Attribution License, which permits unrestricted use, distribution, and reproduction in any medium, provided the original work is properly cited.

\begin{abstract}
The aim of the current research work was to study the physicochemical and biological properties of synthesized zinc doped hydroxyapatite (ZnHAp) nanoparticles with $\mathrm{Zn}$ concentrations $x_{\mathrm{Zn}}=0$ (HAp), $x_{\mathrm{Zn}}=0.07$ (7ZnHAp), and $x_{\mathrm{Zn}}=0.1(10 \mathrm{ZnHAp})$ for potential use in biological applications. The morphology, size, compositions, and incorporation of zinc into hydroxyapatite were characterized by scanning electron microscopy (SEM), transmission electron microscopy (TEM), Fourier Transform Infrared Spectroscopy (FTIR), Raman scattering, and X-Ray Photoelectron Spectroscopy (XPS). In addition, the cytotoxicity of ZnHAp nanoparticles was tested on both E. coli bacteria and human hepatocarcinoma cell line HepG2. The results showed that ZnHAp nanoparticles (HAp, 7ZnHAp, and 10ZnHAp) have slightly elongated morphologies with average diameters between $25 \mathrm{~nm}$ and $18 \mathrm{~nm}$. On the other hand, a uniform and homogeneous distribution of the constituent elements (calcium, phosphorus, zinc, and oxygen) in the ZnHAp powder was noticed. Besides, FTIR and Raman analyses confirmed the proper hydroxyapatite structure of the synthesized ZnHAp nanoparticles with the signature of phosphate, carbonate, and hydroxyl groups. Moreover, it can be concluded that $\mathrm{Zn}$ doping at the tested concentrations is not inducing a specific prokaryote or eukaryote toxicity in HAp compounds.
\end{abstract}

\section{Introduction}

In recent decades, modern medicine rapidly has progressed. In particular, the fields of nanomedicine and tissue engineering have offered new and improved solutions to numerous health problems thus enhancing the quality of life of patients who suffer from various diseases. One of the medical fields that had gained from the development of nanomedicine is the orthopedic surgeries. Ceramic materials are in fact used nowadays either as coating materials for metal prosthesis or as scaffolds for tissue growth [1]. One of the most commonly used biomaterials is hydroxyapatite (HAp) due to its similarity with the main inorganic component of the human natural hard tissue [2]. The biocompatibility of HAp along with its bioactive properties has made it a good candidate for being used as a filling material for bone repair and bone replacement or as an osteoinductive and conductive coating [3]. When used as a coating material for metallic prosthesis, HAp forms physicochemical bonds with the surrounding bone tissue thus promoting bone formation which is essential for the osseointegration of the implant $[4,5]$. To further improve physicochemical and mechanical properties of HAp, researchers have focused their efforts in modifying its structure by doping it with different metallic ions [6]. It was observed that doping HAp with different metallic ions led to changes of the lattice parameters, crystallinity, and other physical properties of the HAp $[4,7]$. One of the trace elements that has an essential role in the human bone 
and plasma is zinc [8]. Being a cofactor in more than 300 enzymes and contributing to the metabolism of proteins, carbohydrates, and lipids [9], zinc has a catalytic, structural, and regulatory role in the human body [9]. Almost $30 \%$ of the total amount of zinc found in the human body is located in the bone tissue, a lack of it inducing serious health problems such as growth retardation, male hypogonadism, or abnormal neurosensory changes [9-12]. Additionally, zinc deficiency induces delayed wound healing, anorexia, weight loss, and an increased susceptibility to infections [9-12]. Therefore, doping HAp with $\mathrm{Zn}^{2+}$ ions offers the opportunity of obtaining an improved biocomposite with enhanced physicochemical properties. Such a material could be used in the future as a coating material for improved prosthesis, reducing the risk of implant rejection by the human body and at the same time improving the quality of life of patients suffering from orthopedic surgeries. In order to synthesize hydroxyapatite with controlled and uniform particle size, various methods such as sol-gel [4], wet-chemical [3], or coprecipitation [12] have been used. The synthesis method that we present in this study provides new information on synthesis parameters and has the potential to be used for synthesis of novel nanostructures. On the other hand, to the best of our knowledge, there are no reliable studies previously reported on the cytotoxicity observed for both E. coli and HepG2 cells. Furthermore, until now, eloquent studies regarding the influence of particle size on cytotoxicity are not presented.

Thus, the aim of this study was to prepare zinc doped hydroxyapatite (HAp, 7ZnHAp, and 10ZnHAp) nanoparticles for future use in possible biological applications. To this end, the cytotoxicity and the antibacterial activity of ZnHAp were also evaluated.

\section{Materials and Methods}

2.1. Materials. In order to synthesize the zinc doped hydroxyapatite (ZnHAp), precursors of calcium nitrate $\left[\mathrm{Ca}\left(\mathrm{NO}_{3}\right)_{2} \cdot 4 \mathrm{H}_{2} \mathrm{O}, 99 \%\right.$ purity, Aldrich, USA], ammonium hydrogen phosphate $\left(\left(\mathrm{NH}_{4}\right)_{2} \mathrm{HPO}_{4}\right.$; Wako Pure Chemical Industries Ltd.), and $\mathrm{Zn}\left(\mathrm{NO}_{3}\right)_{6} \cdot 6 \mathrm{H}_{2} \mathrm{O}$ (Alpha Aesare, Germany, $99.99 \%$ purity) were used.

\subsection{Preparation of Zinc Doped Hydroxyapatite (ZnHAp)} Nanoparticles. ZnHAp was synthetized by a modified coprecipitation method [13]. ZnHAp samples, $\mathrm{Ca}_{10-x}$ $\mathrm{Zn}_{x}\left(\mathrm{PO}_{4}\right)_{6}(\mathrm{OH})_{2}$, with $x_{\mathrm{Zn}}=0,0.07$, and 0.1 , respectively, were synthesized in air at a temperature of $80^{\circ} \mathrm{C}$ using aqueous solutions with various $\mathrm{Zn}:(\mathrm{Zn}+\mathrm{Ca})$ ion ratios, the $[\mathrm{Ca}+$ $\mathrm{Zn}] / \mathrm{P}$ ratio being maintained at $1.67[13,14]$. Appropriate amounts of $\mathrm{Ca}\left(\mathrm{NO}_{3}\right)_{2} \cdot 4 \mathrm{H}_{2} \mathrm{O}$ and $\mathrm{Zn}\left(\mathrm{NO}_{3}\right)_{2} \cdot 6 \mathrm{H}_{2} \mathrm{O}$ were dissolved in deionized water. The $\mathrm{pH}$ value of the suspension was adjusted to 10 adding $28 \%$ ammonia solution. A phosphate solution was prepared by dissolving $\left(\mathrm{NH}_{4}\right)_{2} \mathrm{HPO}_{4}$ in deionized water. The $\left(\mathrm{NH}_{4}\right)_{2} \mathrm{HPO}_{4}$ solution was added to the $\mathrm{Ca}\left(\mathrm{NO}_{3}\right)_{2} \cdot 4 \mathrm{H}_{2} \mathrm{O} / \mathrm{Zn}\left(\mathrm{NO}_{3}\right)_{2} \cdot 6 \mathrm{H}_{2} \mathrm{O}$ solution at room temperature under constant stirring for $72 \mathrm{~h}$ at $80^{\circ} \mathrm{C}$. The resulting precipitate was filtered, washed five times with deionized water, and centrifuged. Finally, the obtained
ZnHAp precipitates were dried in an oven at $80^{\circ} \mathrm{C}$ for 72 hours.

2.3. Structural and Morphological Examination. The crystal phase was determined by powder X-ray diffraction (XRD) measurements using a Bruker D8 Advance diffractometer, with nickel filtered $\mathrm{CuK} \alpha(\lambda=1.5418 \AA)$ radiation and a high efficiency one-dimensional detector (Lynx Eye type) operated in integration mode. The samples were scanned in the $2 \theta$ range $20^{\circ}-80^{\circ}$, with a step of $0.02^{\circ}$ and $34 \mathrm{~s}$ measuring time per step.

The morphology, crystalline structure, and size of ZnHAp nanoparticles were examined by TEM and SEM. For TEM observations, the instrument was Tecnai $120 \mathrm{keV}$ from FEI. Classic modes such bright field (BF) to image the texture of the materials (shape, dimension) and Selected Area Diffraction (SAD) to precise the structure were used. Grain size distribution was determined by measuring the mean diameter, of about 500 particles on the TEM micrographs. For SEM examinations, a Quanta Inspect F scanning electron microscope equipped with an energy dispersive X-ray (EDX) attachment was used.

2.4. Fourier Transform Infrared Spectroscopy. In order to study the structure of the prepared samples, FTIR measurements were performed. The functional groups present in each sample were identified with a Spectrum BX Spectrometer. $1 \%$ of each zinc doped hydroxyapatite powder with $x_{\mathrm{Zn}}=$ $0,0.07$, and 0.1 was mixed and ground with $99 \% \mathrm{KBr}$. The mixture was afterwards pressed at a load of 5 tons for $2 \mathrm{~min}$, resulting in $10 \mathrm{~mm}$ diameter pellets. Each $\mathrm{KBr}-\mathrm{ZnHAp}$ disc was scanned over a wavenumber range between 400 and $4000 \mathrm{~cm}^{-1}$, with a resolution of 4 and 128 times scanning.

2.5. Raman Spectroscopy. Complementary to FTIR measurements, Raman spectroscopy measurements were performed using a RenishawInVia dispersive Raman spectrometer (2012), equipped with a Leica DM microscope and one laser source at $514 \mathrm{~nm}$ (gas-type), Spectra Physics Ar ion laser $(20 \mathrm{~mW})$. The spectra were acquired using the $514 \mathrm{~nm}$ laser with a power of $0.2 \mathrm{~mW}$ and $1800 \mathrm{~L} / \mathrm{mm}$ gratings. All the spectra were registered in the $350-1200 \mathrm{~cm}^{-1}$ spectral range with a resolution below $2 \mathrm{~cm}^{-1}$. Before each measurement, the instrument was calibrated on the internal Si-reference standard $\left(520.6 \pm 0.1 \mathrm{~cm}^{-1}\right)$.

2.6. X-Ray Photoelectron Spectroscopy. XPS measurements were performed with a SPECS Multimethod Surface Analysis System using monochromatic $\mathrm{Al} \mathrm{K} \alpha$ radiation $(1486.6 \mathrm{eV})$. In the analyzer chamber, the vacuum was $p \sim 3 \times 10^{-9}$ torr. The $\mathrm{X}$-rays are emitted by an $\mathrm{Al}$ anticathode with $U=12.5 \mathrm{kV}$ and a filament emission current $I=20 \mathrm{~mA}$. For charge compensation, a FG40 flood gun was used. The provided electron beam had $2 \mathrm{eV}$ and $0.3 \mathrm{~mA}$. The XPS recorded spectrum involved an energy window $w=20 \mathrm{eV}$ with the resolution $R=20 \mathrm{eV}$ and with 400 recording channels. The XPS spectra recorded were processed using Spectral Data Processor v2.3 (SDP) software. 
2.7. Laser Ablation-Inductively Coupled Plasma-Mass Spectrometer (LA-ICP-MS) Analysis. Laser ablation-inductively coupled plasma-mass spectrometer (LA-ICP-MS) analysis was performed on the samples. An elemental XR Thermo Specific, following the procedure described by MotelicaHeino and Donard [15], was used in combination with a VG UV laser probe laser ablation sampling device. Solid samples were prepared as pressed pellets. The repetition rate of the $266 \mathrm{~nm}$ wavelength laser was fixed to $10 \mathrm{~Hz}$. Calibration was performed with certified artificial glass, NIST-610. Measurements were replicated four times to validate the analytical precision of the technique.

2.8. Cytotoxicity Assays. The ZnHAp compounds were dispersed in water to a final concentration of $10 \mathrm{mg} / \mathrm{mL}$.

2.9. HepG2 Cell Viability Assays. HepG2 cell growth assays were performed as previously described [16] with the following modifications: HepG2 cells were grown in Minimum Essential Medium (MEM) supplemented with $10 \% \mathrm{v} / \mathrm{v}$ fetal bovine serum (FBS), $20 \mathrm{mM} \mathrm{L}$-glutamine, $100 \mu \mathrm{g} \cdot \mathrm{mL}^{-1}$ streptomycin, and $100 \mathrm{U} \mathrm{mL}^{-1}$ penicillin. Cells were cultured at $37^{\circ} \mathrm{C}$ in a humidified atmosphere with $5 \% \mathrm{CO}_{2}$.

For cell viability assays, $3 \cdot 10^{5}$ HepG2 cells were seeded in each well of 12-well plates. On the following day, ZnHAp were added at $0,62.5,125,250,500$, and $1000 \mu \mathrm{g} / \mathrm{mL}$ for $24 \mathrm{~h}$. Cells were rinsed twice with PBS, harvested using trypsin, and suspended in $200 \mu \mathrm{L}$ PBS. Cell viability was determined by counting Trypan Blue stained cells in a TC20 Automated Cell Counter (Bio-Rad).

2.10. Antibacterial Activity Assay. The quantitative assay of the minimal inhibitory concentration (MIC, $\mu \mathrm{g} / \mathrm{mL}$ ) was based on twofold serial dilutions performed in 96-well plates. For this purpose, serial dilutions of the tested compounds (ranging between 1000 and $1.95 \mu \mathrm{g} / \mathrm{mL}$ ) were performed to final volumes of $400 \mu \mathrm{L}$ in Luria Bertani medium. Each well was inoculated with the E. coli MG1655 strain at a $600 \mathrm{~nm}$ absorbance of 0.02 . The initial absorbance was measured in a Tecan plate reader. The culture was then performed in deep well plates incubated at $30^{\circ} \mathrm{C}$ with constant shaking of $280 \mathrm{rpm}$ and the final absorbance at $600 \mathrm{~nm}$ was measured after 12 hours.

\section{Results and Discussions}

The X-ray diffraction patterns of hydroxyapatite doped with $\mathrm{Zn}$ (HAp, 7ZnHAp, and 10ZnHAp) are presented in Figure 1. The unique phase was found to be hexagonal hydroxyapatite (standard card ICDD-PDF number 9-432). The width of the diffraction peaks may be due to decrease of particle size and decrease of the apatite crystallinity. Previous results presented by Miyaji et al. [17] revealed that the width of the diffraction peaks suggests that the crystallinity of the apatite significantly decreases with the increase of zinc concentration. The unit cell parameters of ZnHAp were determined by Rietveld refinement of XRD data collected over $2 \theta$ range $20-80^{\circ}$ using MAUD software [18].
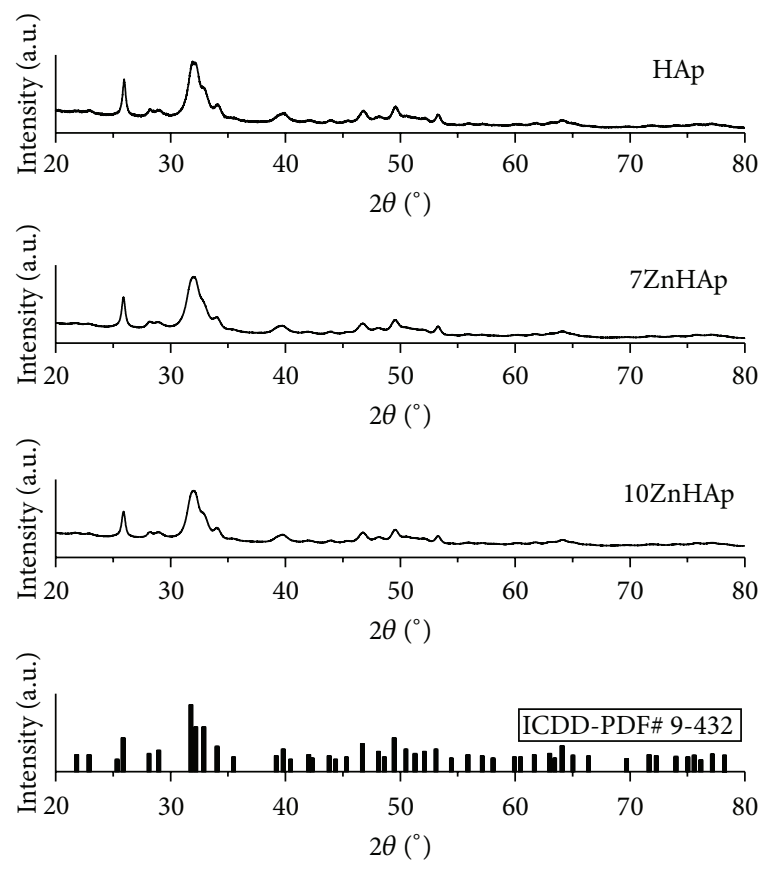

Figure 1: The XRD patterns of HAp, 7ZnHAp, and 10ZnHAp synthesized samples.

The values of lattice parameters "a" and "c" decreased when the $\mathrm{Zn}$ concentration in the samples increased. On the other hand, the average crystallite size decreases with $\mathrm{Zn}$ substitutions, from $23.1879 \mathrm{~nm}$ (HAp) to $19.385 \mathrm{~nm}$ (7ZnHAp) and $15.8763 \mathrm{~nm}$ (10ZnHAp). The results presented in this study are logical and in agreement with those previously presented by Thian et al. [19], since the ionic radius of $\mathrm{Zn}^{2+}$ $(0.074 \mathrm{~nm})$ is smaller in size than $\mathrm{Ca}^{2+}(0.099 \mathrm{~nm})$.

The morphology and elemental composition of ZnHAp samples were examined by scanning electron microscopy (SEM). The obtained results are presented in Figures 2 and 3. The SEM micrographs (Figure 2) revealed that the morphology of the powders is slightly influenced by the increasing quantity of $\mathrm{Zn}$ in the powders. It could be observed that the powders are consisting of nanoparticles with elongated morphology. Also, in the SEM images it could be noticed that the nanoparticles tend to agglomerate due to their nanometric dimensions. The micrographs confirmed the fact that increasing the $\mathrm{Zn}$ content leads to a decrease of the nanoparticles dimensions. EDX spectra of 10ZnHAp samples were acquired (Figure 3). The EDX spectrum confirmed only the presence of the calcium, phosphorus, zinc, and oxygen. On the other hand, the ICP-MS study was performed to investigate the quantities of zinc in the 7ZnHAp and 10ZnHAp powders. The concentration of zinc increases from $13.77 \mathrm{mg} / \mathrm{g}$ (7ZnHAp) to $14.36 \mathrm{mg} / \mathrm{g}$ (10ZnHAp). Our present results are in good agreement with the previous studied performed by Ewald et al. [20].

In Figure 3 the elemental mapping results obtained for the 10ZnHAp powder are presented. The results showed that the powder is composed of calcium, phosphorus, zinc, and oxygen, the main chemical elements of the ZnHAp structure. 


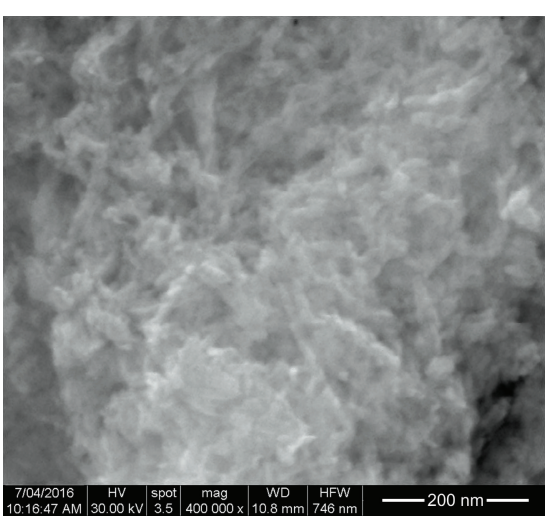

(a)

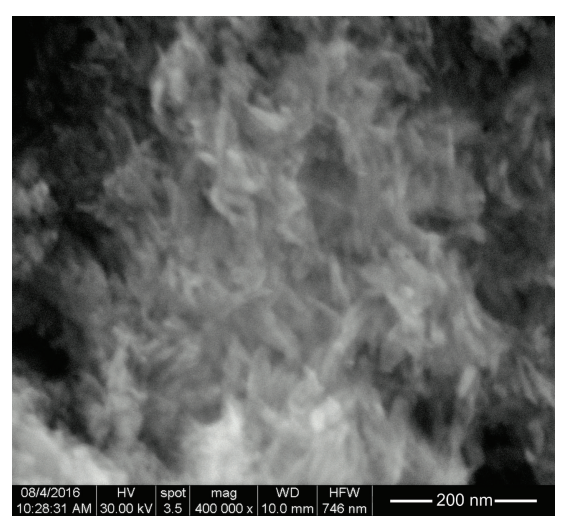

(b)

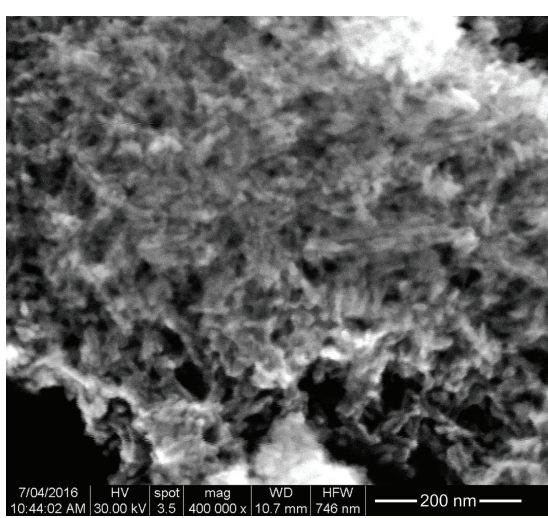

(c)

FIGURE 2: SEM micrograph obtained for the HAp (a), 7ZnHAp (b), and 10ZnHAp (c) powders. The SEM images are recorded with a magnification of $\times 100.000,30 \mathrm{kV}$, and a spot of 3.5 .
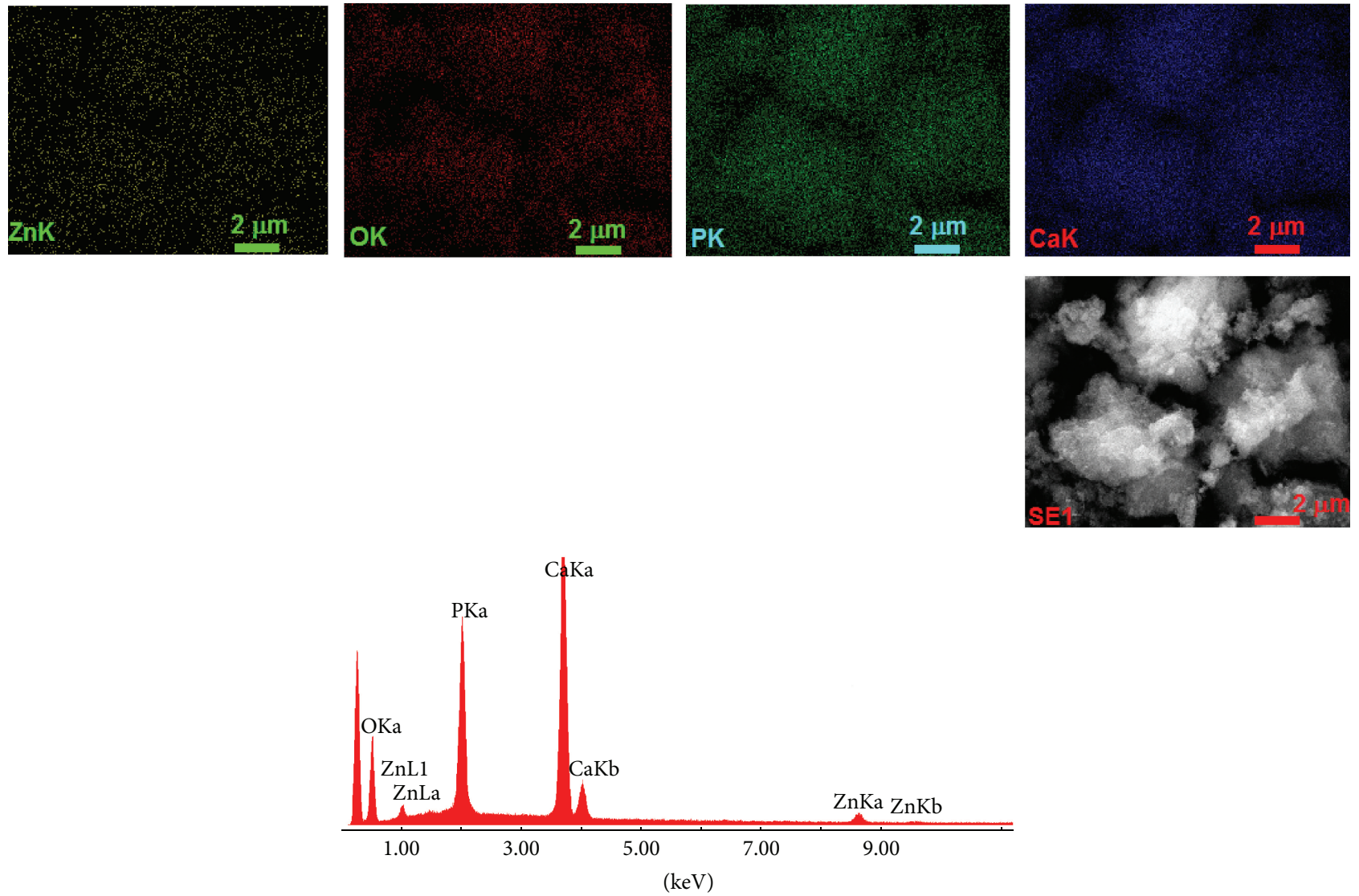

Figure 3: EDX spectra and mapping of 10ZnHAp sample.

Also, the uniform and homogeneous distribution of these elements in the powder could be noticed. Moreover, there was no evidence of any impurities in the sample. The obtained results confirm the presence of $\mathrm{Zn}$ in the powder and its homogeneous distribution through the sample.

The TEM micrographs (Figure 4) revealed information about the texture of the materials (shape, dimension). In order to present the structural evolution of the material containing different concentrations of zinc, the SAD image was inserted. The size distribution is also presented in Figure 3. It could be observed that all the powders (HAp, 7ZnHAp, and 10ZnHAp) are consisting of nanoparticles with a slightly elongated morphology and a mean diameter between $25 \mathrm{~nm}$ and $16 \mathrm{~nm}$. The agglomeration of the nanoparticles was also noticed. A decrease of the nanoparticles size was observed when the concentrations of zinc increased. The SAD analysis confirmed the formation of hydroxyapatite characteristic hexagonal structure. 


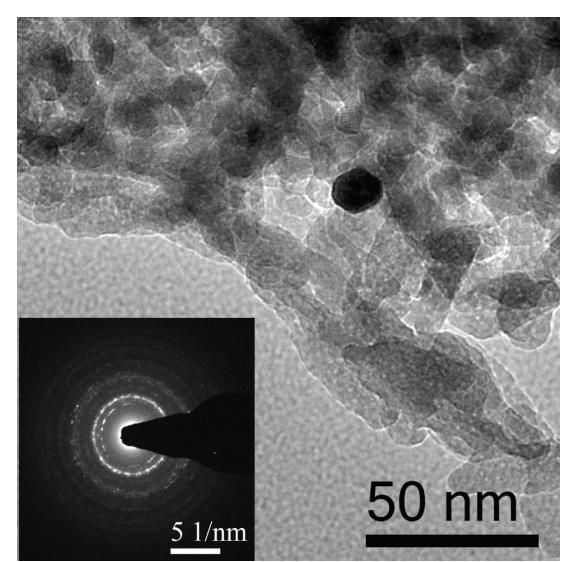

(a)

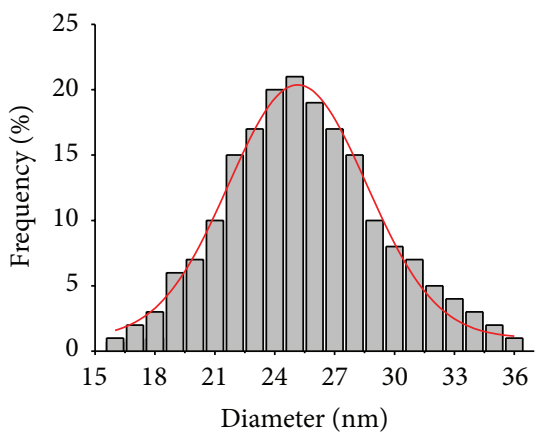

(d)

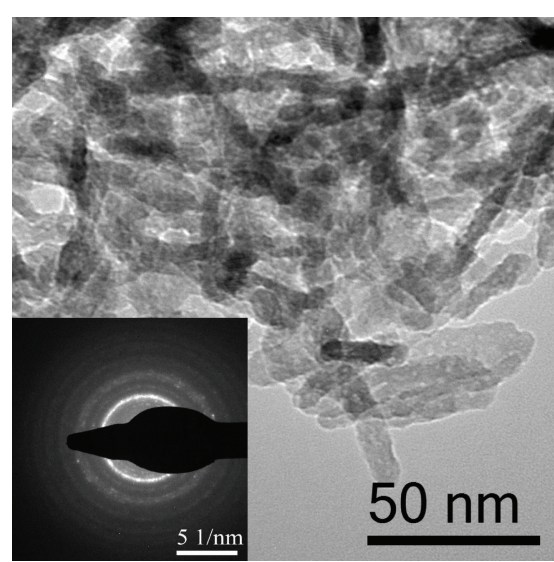

(b)

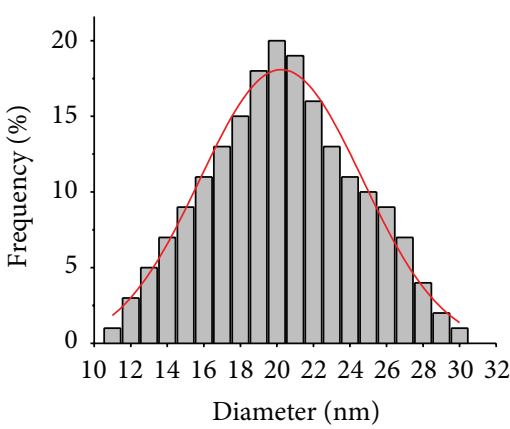

(e)

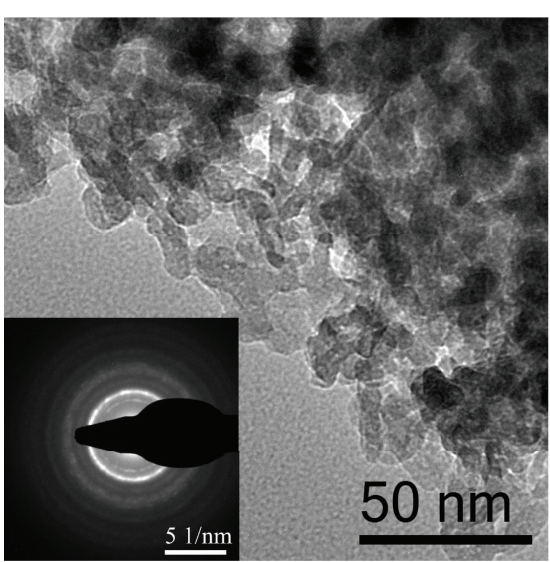

(c)

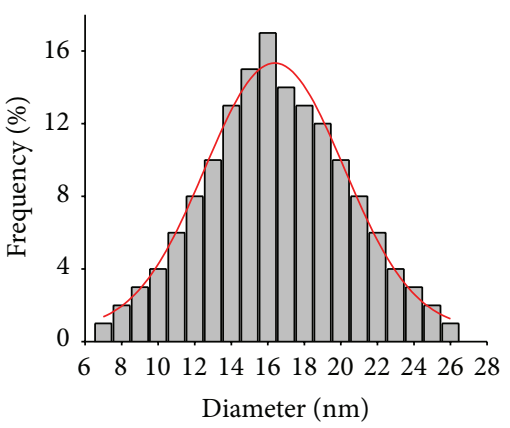

(f)

FIGURE 4: TEM images of the materials containing different concentrations of zinc along with the SAD image inserted (HAp (a); 7ZnHAp (b); 10ZnHAp (c)) and the size distributions (HAp (d); 7ZnHAp (e); 10ZnHAp (f)).

In order to highlight the functional groups of the studied samples, FTIR and Raman measurements were performed. The FTIR spectra acquired for the HAp, 7ZnHAp, and 10ZnHAp samples are presented in Figure 5. On the right bottom side of each spectrum the spectral region between $1600 \mathrm{~cm}^{-1}$ and $4000 \mathrm{~cm}^{-1}$ characteristic of the water lattice is presented.

All the bands found in the three spectra are associated with phosphate, carbonate, and hydroxyl groups and are characteristic of the hydroxyapatite structure. The great majority of the vibrational bands evidenced through FTIR measurements could be attributed to different vibrational modes of the $\mathrm{PO}_{4}{ }^{3-}$ functional group. In this context, the symmetric and antisymmetric stretching modes of the phosphate group were highlighted by the following bands: the band from $962 \mathrm{~cm}^{-1}$ is attributed to the symmetric stretching mode $v_{1}$ $[21,22]$, while the band from $1096 \mathrm{~cm}^{-1}$ is attributed to the $v_{3}$ asymmetric stretching mode [23]. On the other hand, the bending modes of the phosphate group are evidenced by the bands from $566 \mathrm{~cm}^{-1}$ and $602 \mathrm{~cm}^{-1}$, respectively. Both of them are attributed to the $v_{4}$ mode $[21,24,25]$. Furthermore, the band from around $1036 \mathrm{~cm}^{-1}$ is associated with the $\nu_{3}$ bending mode $[21,26]$. There is also another band attributed to the $\mathrm{HPO}_{4}{ }^{2-}$ found in the spectral range $870-880 \mathrm{~cm}^{-1}$ $[21,24]$. However, this one is almost impossible to distinguish due to the fact that it overlaps another vibrational band attributed to the $\mathrm{CO}_{3}{ }^{2-}$ group [26]. The carbonate functional group could be also evidenced by the bands from 1414$1450 \mathrm{~cm}^{-1}$ spectral range [27]. These bands describe the C-O vibrations and their presence suggests that, during the low temperature synthesis, a certain amount of carbonate was incorporated in the samples [27]. The $v_{L}$ vibrational mode of the hydroxyl group is evidenced by the band from around $630 \mathrm{~cm}^{-1}$, while the $v_{S}$ stretching mode of the same functional group is evidenced by the band from around $3572 \mathrm{~cm}^{-1}$ [21, $25,28]$. Generally, the adsorbed water molecules present in the hydroxyapatite structure are described by the vibrational bands from around $1630 \mathrm{~cm}^{-1}[21,29]$ and those from the $3000-3800 \mathrm{~cm}^{-1}$ [25] spectral region. The general behavior of the FTIR spectra exhibits a widening of the peaks and an overall smoothing when the $\mathrm{Zn}$ concentration from the samples increases. This behavior suggests a decrease of the crystallinity of the samples with the increase of zinc concentration.

As for FTIR results, all the peaks presented in the Raman spectra are associated with the functional groups characteristic of hydroxyapatite (Figure 6).

They are all attributed to different stretching and bending modes of the phosphate groups. The totally symmetric stretching mode $v_{1}$ of the P-O bond is described by the presence of the very sharp band from $961 \mathrm{~cm}^{-1}$, while the triply degenerated asymmetric stretching mode $v_{3}$ of 

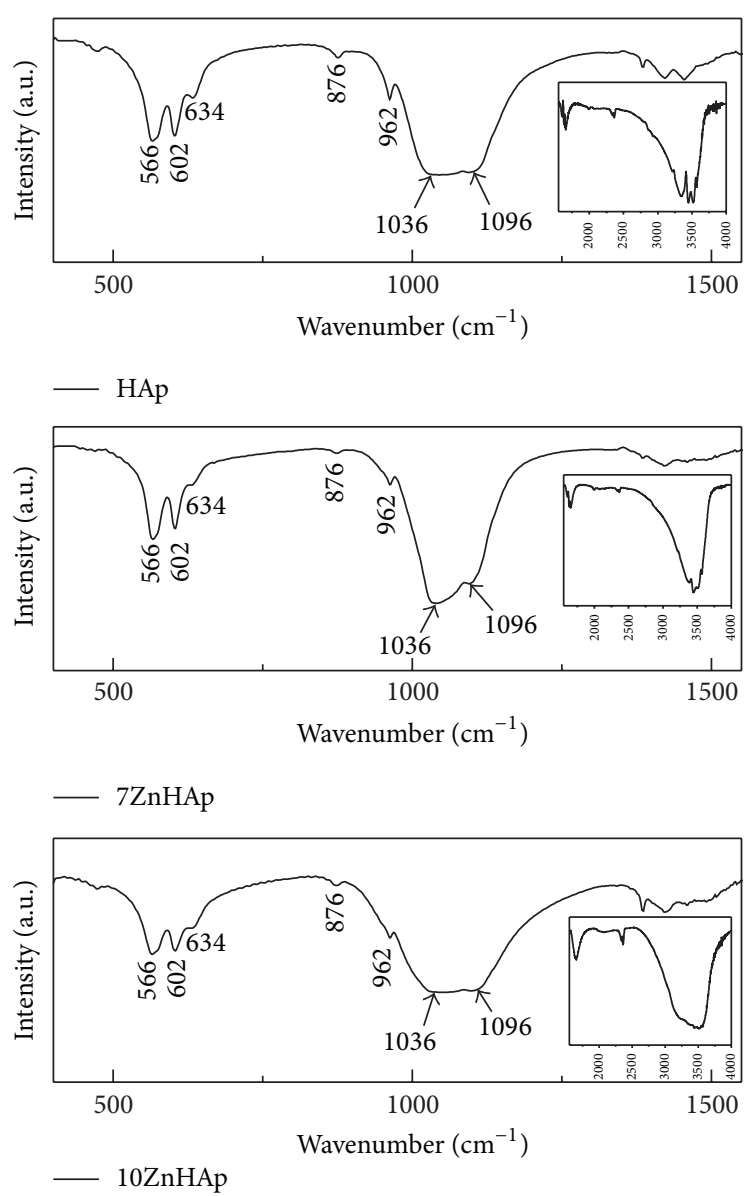

FIgURE 5: FTIR of HAp, 7ZnHAp, and 10ZnHAp.

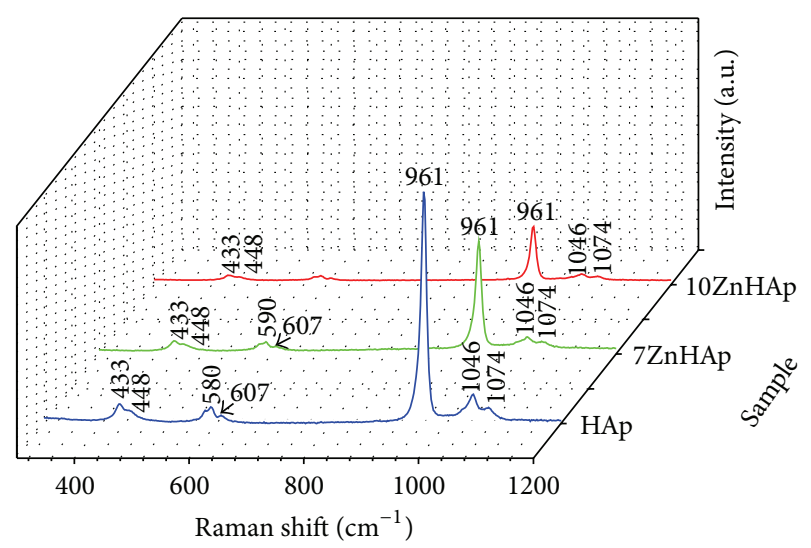

Figure 6: Raman spectra of HAp, 7ZnHAp, and 10ZnHAp.

the same $\mathrm{P}-\mathrm{O}$ bond is evidenced by the peaks at $1046 \mathrm{~cm}^{-1}[21$, 30 ] and $1074 \mathrm{~cm}^{-1}$ [31], respectively. On the other hand, the bands at $433 \mathrm{~cm}^{-1}$ and $448 \mathrm{~cm}^{-1}$ are attributed to the $v_{2}$ double degenerated bending mode of the phosphate group [21, 30, 31], while the bands at $580 \mathrm{~cm}^{-1}, 607 \mathrm{~cm}^{-1}$, and $590 \mathrm{~cm}^{-1}$ [31] are associated with the $\nu_{4}$ triple degenerated bending mode. All the mentioned vibrational peaks which describe the bending modes of the $\mathrm{PO}_{4}{ }^{3-}$ functional group describe the vibrations of the O-P-O bonds [21, 30, 31].

Although all these Raman bands are present in the three spectra, it is interesting to note that their intensities gradually decrease as $\mathrm{Zn}$ concentration in the samples increases.

The XPS general spectra for the 7ZnHAp and 10ZnHAp samples, after the powders were dried at $40^{\circ} \mathrm{C}$, are presented in Figures 7(a)-7(b). Figure 6 revealed the presence of Ca 2p, P $2 \mathrm{p}, \mathrm{O} 1 \mathrm{~s}$, and Zn 2p elements in the XPS spectra of the ZnHAp samples with $x_{\mathrm{Zn}}=0.07$ and $x_{\mathrm{Zn}}=0.1$.

The $C$ 1s peak that can be seen at a binding energy $\left(E_{b}\right)$ of $284 \mathrm{eV}$ is due to the adsorbed carbon. The photoelectron peak for $\mathrm{O} 1 \mathrm{~s}$ can be observed at $E_{b}=531 \mathrm{eV}$ and P 2p at around $133 \mathrm{eV}$. The spectra of Ca 2p, P 2p, and Zn 2p are also presented in Figure 7(b). The XPS spectral peaks for Ca 2p in the ZnHAp powders are assigned to the $2 \mathrm{p} 3 / 2$ electronic states of $\mathrm{Ca}(\mathrm{II})$. In the 10ZnHAp sample two peaks were observed at 347 , 27 and 350, $76 \mathrm{eV}$. In previous studies on "chemical analysis of silica doped hydroxyapatite biomaterials consolidated by a spark plasma sintering method," Xu and Khor [32] showed that the calcium atoms are related with a phosphate group $\left(\mathrm{PO}_{4}{ }^{3-}\right)$. The spectrum of $\mathrm{P} 2 \mathrm{p}$ is composed of two components that were identified at around $133.09 \mathrm{eV}$ and $133.78 \mathrm{eV}$. The "XPS study of apatite-based coatings prepared by sol-gel technique" conducted by Kačiulis et al. [33] showed that these two values of binding energy obtained for $\mathrm{P} 2 \mathrm{p}$ spectrum are characteristic of HAp. XPS characterizations of ZnHAp powders revealed that the $\mathrm{Zn} 2 \mathrm{p}$ spectrum exhibits two peaks. The two $\mathrm{Zn}$ related peaks of the 10ZnHAp sample can be observed at $1022 \mathrm{eV}$ and 1023, $95 \mathrm{eV}$. According to the studies conducted by Zhang et al. [34] these two peaks can be attributed to the $2 \mathrm{p} 3 / 2$ and $2 \mathrm{p} 1 / 2$ electronic states of $\mathrm{Zn}$ (II).

In the last decade, increased efforts have been directed to promoting the use of nanoparticles in different biomedical applications including nanomedicine. In this research study, the cytotoxicity of the three compounds HAp, 7ZnHAp, and 10ZnHAp has been tested both on the E. coli bacteria and on the human hepatocarcinoma cell line HepG2.

The biocidal effects for three different samples are quite similar with a growth inhibition starting at $250 \mu \mathrm{g} / \mathrm{mL}$ and a significant growth inhibition observed at 500 and $1000 \mu \mathrm{g} / \mathrm{mL}$ (Figure 7(a)). The similarity between HAp, 7ZnHAp, and 10ZnHAp showed that this low toxicity is not related to the presence of zinc but is most probably due to a mechanical effect on the bacteria induced by the large particles present in solution. This hypothesis is strengthened by the slightly lower toxicity observed with 10ZnHAp that contains more $\mathrm{Zn}$ but forms smaller particles.

Interestingly, HepG2 cell viability is only moderately affected by 7ZnHAp and 10ZnHAp with a cell death around $20 \%$ for all tested conditions but the control (Figure 8(b)). HAp induced a slightly higher cell death than ZnHAp at $62.5,125$, and $250 \mu \mathrm{g} / \mathrm{mL}$ in a dose-dependent manner reaching $40 \%$ mortality. The toxicity is then decreasing for the higher concentrations 500 and $1000 \mu \mathrm{g} / \mathrm{mL}$ reaching only $20 \%$ cell death (Figure 8(b)), a similar level to the ZnHAp. However, HAp and the ZnHAp have a particulate nature in the culture media that can lead to a decrease of the overall cell count per sample for the higher concentrations. This is not 


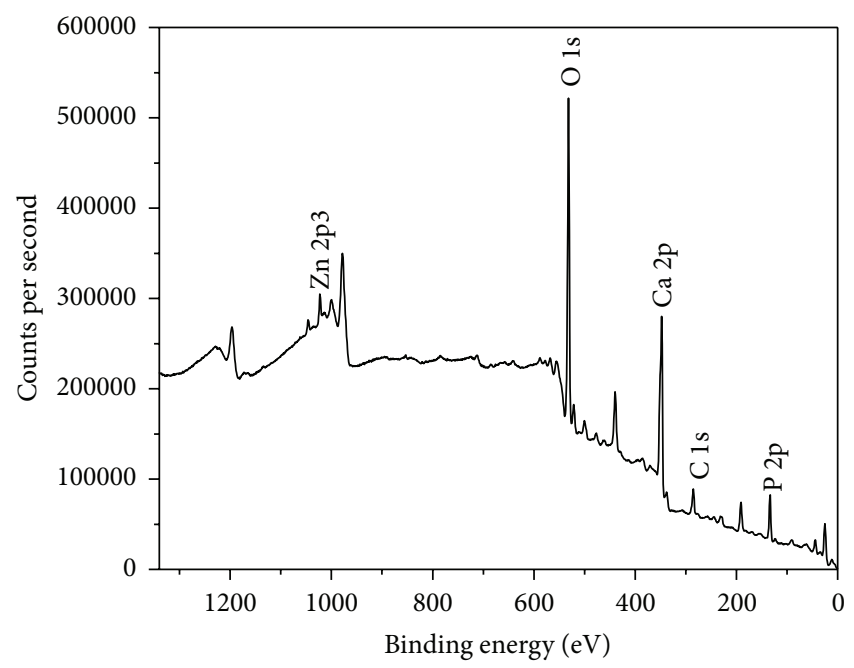

(a)

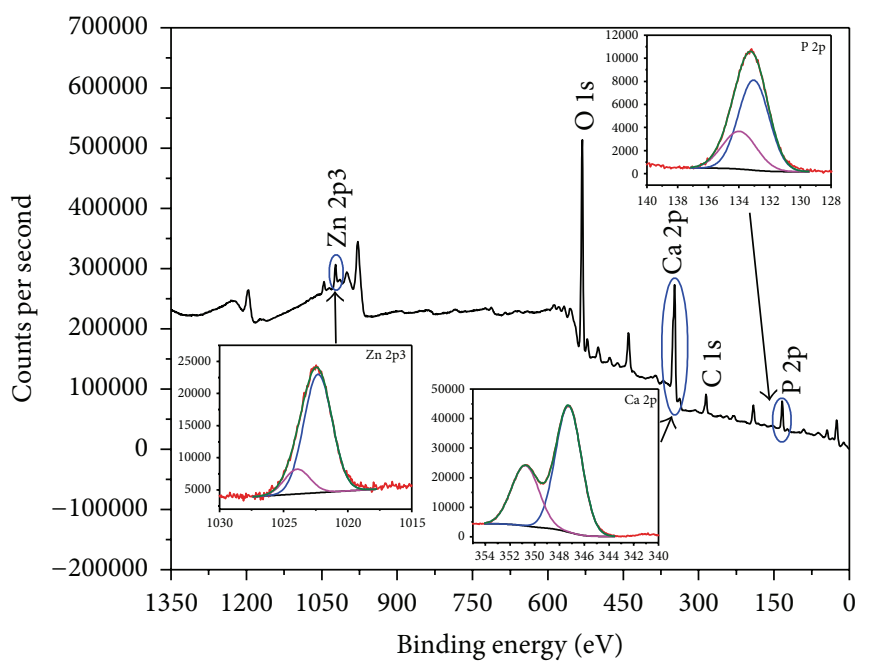

(b)

Figure 7: XPS spectra of (a) 7ZnHAp and (b) 10ZnHAp along with the highlighted energies associated with the main constituent elements.

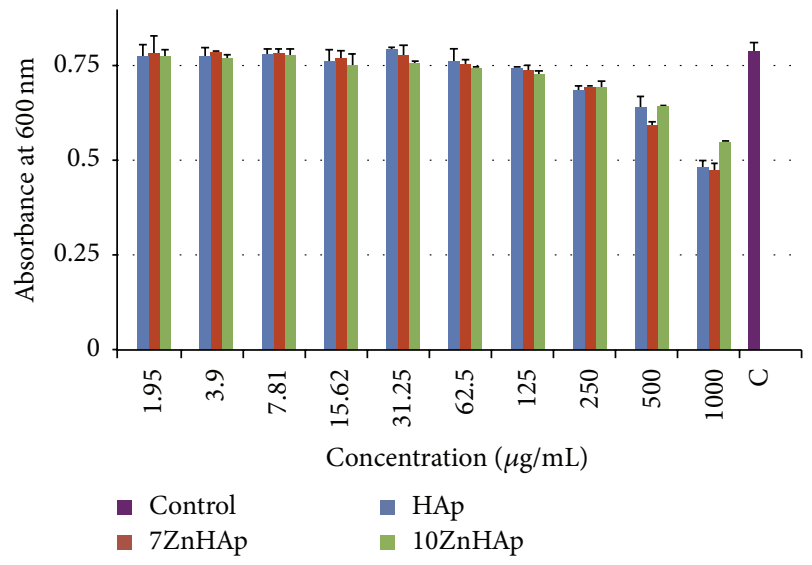

(a)

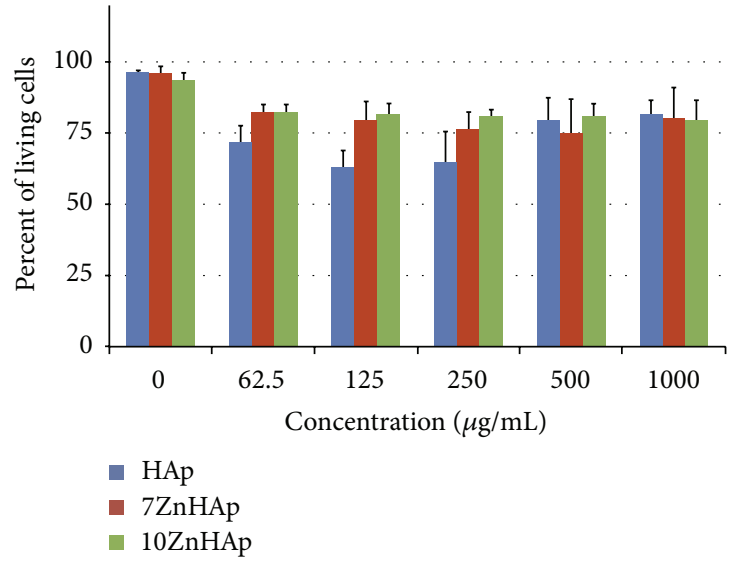

(b)

FIGURE 8: Viability assays. (a) $600 \mathrm{~nm}$ absorbance increase after 12 hours' E. coli cell growth in $\mathrm{LB}$ at $30^{\circ} \mathrm{C}$ in the presence of $\mathrm{HAp}, 7 \mathrm{ZnHAp}$, and 10ZnHAp at concentrations between 1.95 and $1000 \mu \mathrm{g} / \mathrm{mL}$. (b) HepG2 viability after $24 \mathrm{~h}$ exposure to HAp, 7ZnHAp, and 10ZnHAp at concentrations between 62.5 and $1000 \mu \mathrm{g} / \mathrm{mL}$. Error bars are calculated from at least 3 independent experiments.

negligible for HAp that forms the larger particle. Therefore, the higher survival at 500 and $1000 \mu \mathrm{g} / \mathrm{mL}$ of HAp is probably overestimated.

Altogether, one can conclude that $\mathrm{Zn}$ doping at the tested concentrations is not inducing a specific prokaryote or eukaryote toxicity in HAp compounds. The cytotoxicity observed for both E. coli and HepG2 cells is most probably due to deleterious interactions between the large particles formed by the HAp and ZnHAp and cell membranes. Indeed, HAp that formed the larger particles induce the highest lethality in the different experiments performed in this study.

This study clearly revealed that the activity of ZnHAp nanoparticles against HepG2 cells was significantly dependent on the particle size. In agreement with our results, the existing studies in the literature $[35,36]$ have shown that the cytotoxicity of ZnHAp nanoparticles against HepG2 cells is dependent on their size. The increase of the zinc concentration in the HAp structure led to a decrease of the particle size. Therefore, the particle size decreases as the percentage of the dopant (zinc) increases. Also, Chithrani et al. [37] reported in their studies that the cellular uptake kinetics and saturation concentrations are highly dependent upon the physical dimensions of the nanoparticles. On the other hand, Osaki et al. [38] established that semiconductor nanoparticles with a diameter of $50 \mathrm{~nm}$ penetrated into cells via receptormediated endocytosis more easily than smaller nanoparticles.

Recently, the studies concerning the correlation between particle properties and their cytotoxicity and biostability [39] showed that, regarding the cellular uptake, rod-shaped hydroxyapatite nanoparticles have a considerable advantage compared to spherical nanoparticles. 
The goal of research aimed at orthopedic and dental fields is to produce high quality materials for bone substitutions, which are also able to repair or replace bone tissue. It is known that infections affect the regeneration ability of tissues. Also, Romanò et al. [40] showed that infections that may occur in time determine a major limitation to long-term utility of medical implants. Recently it was shown that the nanoparticles represent a feasible alternative for the treatment of various diseases because of their unique biological effect caused by their new properties determined by morphology, size, and surface at nanoscale.

In this study, we prepared zinc doped hydroxyapatite nanoparticles with elongated morphology and a mean diameter between $25 \mathrm{~nm}$ and $16 \mathrm{~nm}$. Structural analysis confirmed the homogeneous distribution of $\mathrm{Zn}$ in the powders and the formation of hydroxyapatite characteristic hexagonal structure. Furthermore, the biological investigations suggested that the cytotoxicity of the studied samples on both E. coli and HepG2 cells depends on the particle size. Based on previous studies which showed that metal ions released from metal oxide nanoparticles contribute to the cytotoxicity of the compounds [41], Venkatasubbu et al. [35] established that the release of $\mathrm{Ca}^{2+}$ and $\mathrm{Zn}^{2+}$ ions from pure hydroxyapatite and zinc doped hydroxyapatite is responsible for the cytotoxicity. On the other hand, recent studies [35] proved that the cytotoxic and genotoxic mechanisms of HAp and zinc doped HAp are related to their membrane penetration capability and their apoptosis activity. In addition, recent studies showed that $M$. luteus, a Gram-positive bacteria, commonly found in mucous membranes, was highly inhibited by nanoHAp and doped nano-ZnHAp [42]. On the other hand, Huang et al. [43] showed in their study on "anticorrosive effects and in vitro cytocompatibility of calcium silicate/zinc doped hydroxyapatite composite coatings on titanium" that the high cytocompatibility of calcium silicate/zinc doped hydroxyapatite could be mainly attributed to the combination of microporous surface effects and ion release $\left(\mathrm{Zn}^{2+}\right.$ and $\mathrm{Si}^{4+}$ ). The $\mathrm{Zn}$-Ag-HAp nanoparticles were found to be compatible with in vitro experiments and having potential antibacterial properties and could be a promising candidate for future biomedical applications [44]. In addition, the cell response tests, conducted by Ding et al. [45], established that MC3T3-E1 cells on ZnHAp coating clearly enhanced the in vitro cytocompatibility of $\mathrm{Ti}$ compared with HAp coating. Moreover, Venkatasubbu et al. [35] demonstrated that specific physicochemical properties of nanoparticles can alter their assimilation ability. In accordance with our results, they showed that the concentration and size of the nanoparticles are very important in the assimilation of the substance. Finally, we might conclude that controlled physical and chemical properties of nanoparticles play an important role in the cell absorption.

\section{Conclusions}

In this study the morphological, structural, and biological properties of zinc doped hydroxyapatite nanopowders were analyzed. For this purpose, samples with various zinc concentrations (HAp, 7ZnHAp, and 10ZnHAp) were synthesized.
The SEM micrographs revealed a decrease of the particles size when the zinc concentration from the samples increased. These findings were also supported by TEM images. Furthermore, the size distribution showed that the nanoparticle diameters vary between $19 \mathrm{~nm}$ and $25 \mathrm{~nm}$. Also, the SAED investigation revealed the formation of the hydroxyapatite characteristic hexagonal structure.

However, both FTIR and Raman spectra of all three samples revealed a decrease of the peak intensities when the zinc concentration increased. This behavior suggests a decrease of the sample crystallinities with the increase of zinc content. On the other hand, the presence of the hydroxyapatite characteristic structure was also supported by XPS spectra obtained for the two zinc doped hydroxyapatite samples with $x_{\mathrm{Zn}}=0.07$ and $x_{\mathrm{Zn}}=0.1$, respectively.

Lastly, biological investigations were performed for the three samples (HAp, 7ZnHAp, and 10ZnHAp) both on the E. coli bacteria and on the human hepatocarcinoma cell line HepG2. The results suggested that the cytotoxicity of the studied samples on both E. coli and HepG2 cells depends on the particle size. Considering that the size of the nanoparticles decreased when the zinc concentration from the samples increased, the highest death rate of the cells was achieved for the HAp sample, while the lowest death rate was achieved for the 10ZnHAp sample.

Our research proved that the new adapted coprecipitation method is a time and cost efficient synthesis method for obtaining zinc doped hydroxyapatite nanoparticles with promising properties for various biomedical applications. It can be concluded that the results presented in this paper form the premises for future studies on high quality materials that could be used eventually in various biomedical applications.

\section{Competing Interests}

The authors report no conflict of interests in this work.

\section{Acknowledgments}

The authors are grateful to Dr. Catalin Constantin Negrila for XPS measurements. This work was supported by the IFACEA C4-05/2014 project and Core Program PN 16-48/2016 (MS-FISCOMAT).

\section{References}

[1] M. H. Santos, L. G. Dias Heneine, and H. S. Mansur, "Synthesis and characterization of calcium phosphate/collagen biocomposites doped with $\mathrm{Zn}^{2+}$, Materials Science and Engineering C, vol. 28, no. 4, pp. 563-571, 2008.

[2] Y. Tang, H. F. Chappell, M. T. Dove, R. J. Reeder, and Y. J. Lee, "Zinc incorporation into hydroxylapatite," Biomaterials, vol. 30, no. 15, pp. 2864-2872, 2009.

[3] F. Ren, R. Xin, X. Ge, and Y. Leng, "Characterization and structural analysis of zinc-substituted hydroxyapatites," Acta Biomaterialia, vol. 5, no. 8, pp. 3141-3149, 2009.

[4] E. Jallot, J. M. Nedelec, A. S. Grimault et al., "STEM and EDXS characterisation of physico-chemical reactions at the periphery of sol-gel derived Zn-substituted hydroxyapatites during 
interactions with biological fluids," Colloids and Surfaces B: Biointerfaces, vol. 42, no. 3-4, pp. 205-210, 2005.

[5] S. Raita, N. Cornila, V. Danacu et al., "Morphological studies on the liver in Struthio camelus," Anatomia Histologya Embryologya, vol. 43, no. 1, pp. 74-75, 2014.

[6] C. S. Ciobanu, A. Groza, S. L. Iconaru et al., "Antimicrobial activity evaluation on silver doped hydroxyapatite/polydimethylsiloxane composite layer," BioMed Research International, vol. 2015, Article ID 926513, 13 pages, 2015.

[7] G. Daculsi, R. Z. LeGeros, M. Heughebaert, and I. Barbieux, "Formation of carbonate-apatite crystals after implantation of calcium phosphate ceramics," Calcified Tissue International, vol. 46, no. 1, pp. 20-27, 1990.

[8] E. Fujii, M. Ohkubo, K. Tsuru et al., "Selective protein adsorption property and characterization of nano-crystalline zinccontaining hydroxyapatite," Acta Biomaterialia, vol. 2, no. 1, pp. 69-74, 2006.

[9] C. O. Molokwu and Y. V. Li, "Zinc homeostasis and bone mineral density," Ohio Research and Clinical Review, vol. 15, pp. $6-15,2006$.

[10] R. Tudor, P. D. Zalewski, and R. N. Ratnaike, "Zinc in health and chronic disease," Journal of Nutrition, Health and Aging, vol. 9, no. 1, pp. 45-51, 2005.

[11] V. Danacu, S. Raita, and C. Ionita, "Morphological studies on visceral lymph nodes of the abdominal cavity in the rabbit," Anatomia Histologya Embryologya, vol. 43, no. 1, pp. 34-35, 2014.

[12] C. S. Ciobanu, F. Massuyeau, L. V. Constantin et al., "Structural and physical properties of antibacterial Ag-doped nanohydroxyapatite synthesized at 100॰C," Nanoscale Letters, vol. 6, no. 1, pp. 613-620, 2011.

[13] C. S. Ciobanu, S. L. Iconaru, F. Massuyeau, L. V. Constantin, A. Costescu, and D. Predoi, "Synthesis, structure, and luminescent properties of europium-doped hydroxyapatite nanocrystalline powders," Journal of Nanomaterials, vol. 2012, Article ID 942801, 9 pages, 2012.

[14] C. S. Ciobanu, C. L. Popa, and D. Predoi, "Sm:HAp nanopowders present antibacterial activity against Enterococcus faecalis," Journal of Nanomaterials, vol. 2014, Article ID 780686, 9 pages, 2014.

[15] M. Motelica-Heino and O. F. X. Donard, "Comparison of UV and IR laser ablation ICP-MS on silicate reference materials and implementation of normalisation factors for quantitative measurements," Geostandards Newsletter, vol. 25, no. 2-3, pp. 345-359, 2001.

[16] M. Cuillel, M. Chevallet, P. Charbonnier et al., "Interference of $\mathrm{CuO}$ nanoparticles with metal homeostasis in hepatocytes under sub-toxic conditions," Nanoscale, vol. 6, no. 3, pp. 17071715, 2014.

[17] F. Miyaji, Y. Kono, and Y. Suyama, "Formation and structure of zinc-substituted calcium hydroxyapatite," Materials Research Bulletin, vol. 40, no. 2, pp. 209-220, 2005.

[18] L. Lutterotti, "Total pattern fitting for the combined size-strainstress-texture determination in thin film diffraction," Nuclear Instruments and Methods in Physics Research, Section B: Beam Interactions with Materials and Atoms, vol. 268, no. 3-4, pp. 334340, 2010.

[19] E. S. Thian, T. Konishi, Y. Kawanobe et al., "Zinc-substituted hydroxyapatite: a biomaterial with enhanced bioactivity and antibacterial properties," Journal of Materials Science: Materials in Medicine, vol. 24, no. 2, pp. 437-445, 2013.
[20] A. Ewald, D. Hösel, S. Patel, L. M. Grover, J. E. Barralet, and U. Gbureck, "Silver-doped calcium phosphate cements with antimicrobial activity," Acta Biomaterialia, vol. 7, no. 11, pp. 40644070, 2011.

[21] S. Koutsopoulos, "Synthesis and characterization of hydroxyapatite crystals: a review study on the analytical methods," Journal of Biomedical Materials Research, vol. 62, no. 4, pp. 600-612, 2002.

[22] C. B. Baddiel and E. E. Berry, "Spectra-structure correlations in hydroxyapatite and fluorapatite," Spectrochimica Acta A, vol. 22, pp. 1407-1416, 1966.

[23] I. Rehman and W. Bonfield, "Characterization of hydroxyapatite and carbonated apatite by photo acoustic FTIR spectroscopy," Journal of Materials Science: Materials in Medicine, vol. 8, no. 1, pp. 1-4, 1997.

[24] K. P. Tank, P. Sharma, D. K. Kanchan, and M. J. Joshi, "FTIR, powder XRD, TEM and dielectric studies of pure and zinc doped nano-hydroxyapatite," Crystal Research and Technology, vol. 46, no. 12, pp. 1309-1316, 2011.

[25] S. J. Joris and C. H. Amberg, "The nature of deficiency in nonstoichiometric hydroxyapatites. II. Spectroscopic studies of calcium and strontium hydroxyapatites," Journal of Physical Chemistry, vol. 75, no. 20, pp. 3172-3178, 1971.

[26] L. Berzina-Cimdina and N. Borodajenko, "Research of calcium phosphates using fourier transform infrared spectroscopy," in Infrared Spectroscopy-Materials Science, Engineering and Technology, T. Theophanides, Ed., InTech, 2012.

[27] I. R. de Lima, A. M. Costa, I. N. Bastos, J. M. Granjeiro, and G. D. A. Soares, "Development and characterization of $5 \% \mathrm{~mol} \mathrm{Zn}$ bioceramic in granular form," Materials Research, vol. 9, no. 4, pp. 399-403, 2006.

[28] J. Arends, J. Christoffersen, M. R. Christoffersen et al., "A calcium hydroxyapatite precipitated from an aqueous solution: an international multimethod analysis," Journal of Crystal Growth, vol. 84, no. 3, pp. 515-532, 1987.

[29] R. Z. LeGeros, "The unit-cell dimensions of human enamel apatite: effect of chloride incorporation," Archives of Oral Biology, vol. 20, no. 1, pp. 63-71, 1975.

[30] G. R. Sauer, W. B. Zunic, J. R. Durig, and R. E. Wuthier, "Fourier transform raman spectroscopy of synthetic and biological calcium phosphates," Calcified Tissue International, vol. 54, no. 5, pp. 414-420, 1994.

[31] P. N. de Aza, F. Guitian, and C. Santos, "Vibrational investigation of calcium phosphate compounds. 2. Comparison between hydroxyapatite and -tricalcium phosphate," Chemistry of Materials, vol. 9, no. 4, pp. 916-922, 1997.

[32] J. L. Xu and K. A. Khor, "Chemical analysis of silica doped hydroxyapatite biomaterials consolidated by a spark plasma sintering method," Journal of Inorganic Biochemistry, vol. 101, no. 2, pp. 187-195, 2007.

[33] S. Kačiulis, G. Mattogno, L. Pandolfi, M. Cavalli, G. Gnappi, and A. Montenero, "XPS study of apatite-based coatings prepared by sol-gel technique," Applied Surface Science, vol. 151, no. 1, pp. 1-5, 1999.

[34] H. Zhang, Y. Liang, X. Wu, and H. Zheng, "Enhanced photocatalytic activity of $(\mathrm{Zn}, \mathrm{N})$-codoped $\mathrm{TiO}_{2}$ nanoparticles," Materials Research Bulletin, vol. 47, no. 9, pp. 2188-2192, 2012.

[35] G. D. Venkatasubbu, S. Ramasamy, G. S. Avadhani, L. Palanikumar, and J. Kumar, "Size-mediated cytotoxicity of nanocrystalline titanium dioxide, pure and zinc-doped hydroxyapatite nanoparticles in human hepatoma cells," Journal of Nanoparticle Research, vol. 14, article 819, 2012. 
[36] W. Jiang, B. Y. S. Kim, J. T. Rutka, and W. C. W. Chan, "Nanoparticle-mediated cellular response is size-dependent," Nature Nanotechnology, vol. 3, no. 3, pp. 145-150, 2008.

[37] B. D. Chithrani, A. A. Ghazani, and W. C. W. Chan, "Determining the size and shape dependence of gold nanoparticle uptake into mammalian cells," Nano Letters, vol. 6, no. 4, pp. 662-668, 2006.

[38] F. Osaki, T. Kanamori, S. Sando, T. Sera, and Y. Aoyama, "A quantum dot conjugated sugar ball and its cellular uptake. On the size effects of endocytosis in the subviral region," Journal of the American Chemical Society, vol. 126, no. 21, pp. 6520-6521, 2004.

[39] M. Motskin, D. M. Wright, K. Muller et al., "Hydroxyapatite nano and microparticles: correlation of particle properties with cytotoxicity and biostability," Biomaterials, vol. 30, no. 19, pp. 3307-3317, 2009.

[40] C. L. Romanò, M. Toscano, D. Romanò, and L. Drago, "Antibiofilm agents and implant-related infections in orthopaedics: where are we?" Journal of Chemotherapy, vol. 25, no. 2, pp. 6580, 2013.

[41] K. Subramani, H. Hosseinkhani, A. Khraisat, M. Hosseinkhani, and Y. Pathak, "Targeting nanoparticles as drug delivery systems for cancer treatment," Current Nanoscience, vol. 5, no. 2, pp. 135-140, 2009.

[42] K. P. Tank, K. S. Chudasama, V. S. Thaker, and M. J. Joshi, "Pure and zinc doped nano-hydroxyapatite: synthesis, characterization, antimicrobial and hemolytic studies," Journal of Crystal Growth, vol. 401, pp. 474-479, 2014.

[43] Y. Huang, H. Zhang, H. Qiao et al., "Anticorrosive effects and in vitro cytocompatibility of calcium silicate/zinc-doped hydroxyapatite composite coatings on titanium," Applied Surface Science, vol. 357, pp. 1776-1784, 2015.

[44] N. Iqbal, M. R. A. Kadir, N. H. Mahmood et al., "Characterization, antibacterial and in vitro compatibility of zinc-silver doped hydroxyapatite nanoparticles prepared through microwave synthesis," Ceramics International, vol. 40, no. 3, pp. 45074513, 2014.

[45] Q. Ding, X. Zhang, Y. Huang, Y. Yan, and X. Pang, "In vitro cytocompatibility and corrosion resistance of zinc-doped hydroxyapatite coatings on a titanium substrate," Journal of Materials Science, vol. 50, no. 1, pp. 189-202, 2015. 

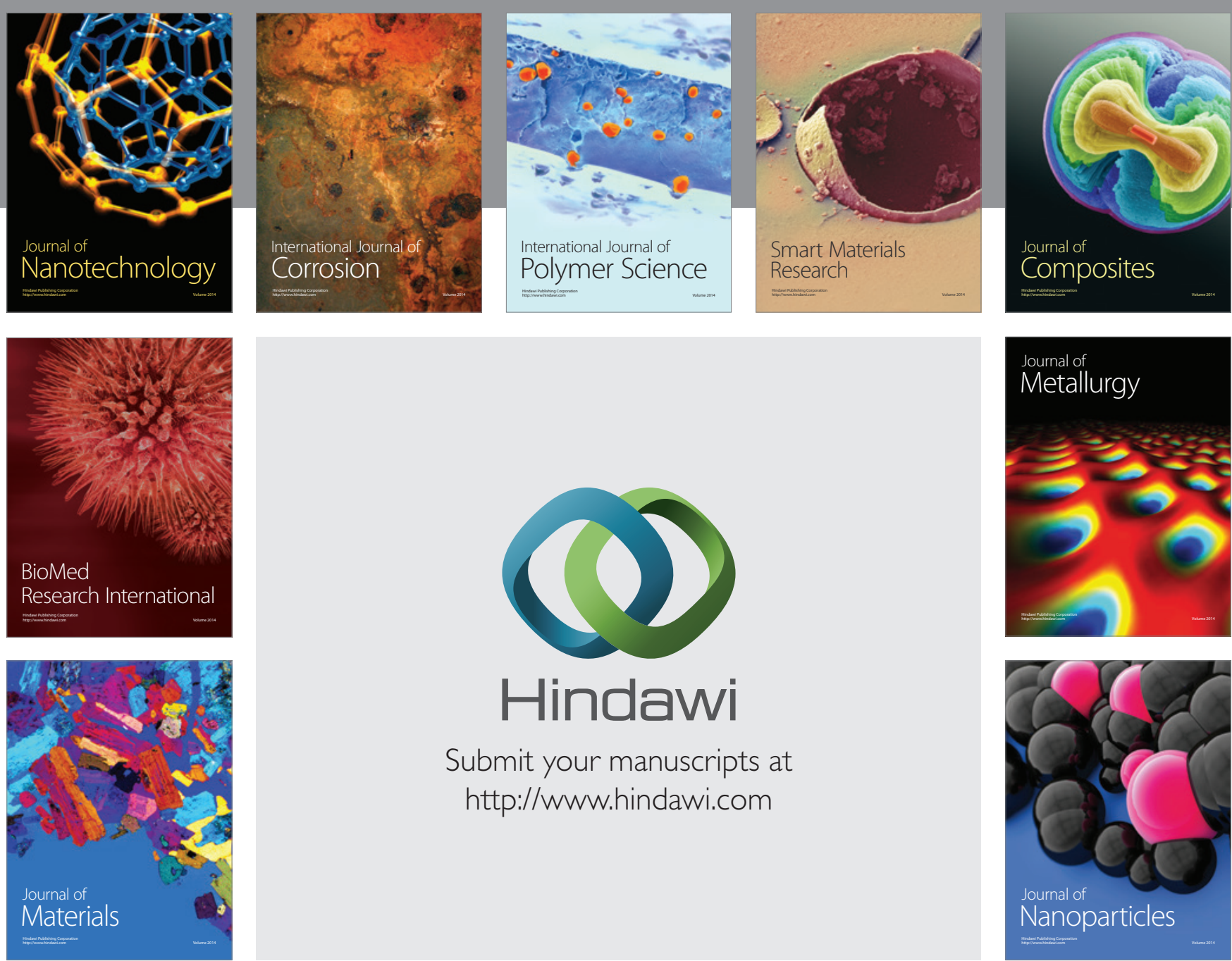

\section{Hindawi}

Submit your manuscripts at

http://www.hindawi.com

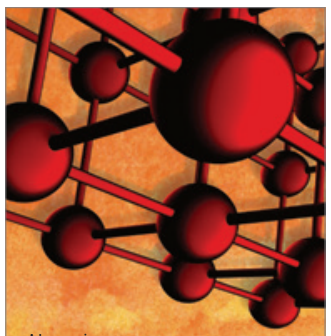

Materials Science and Engineering
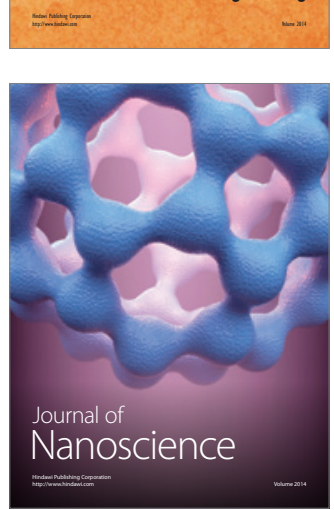
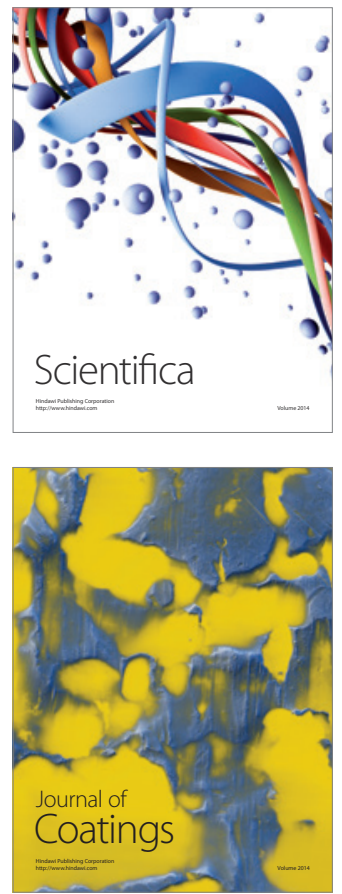
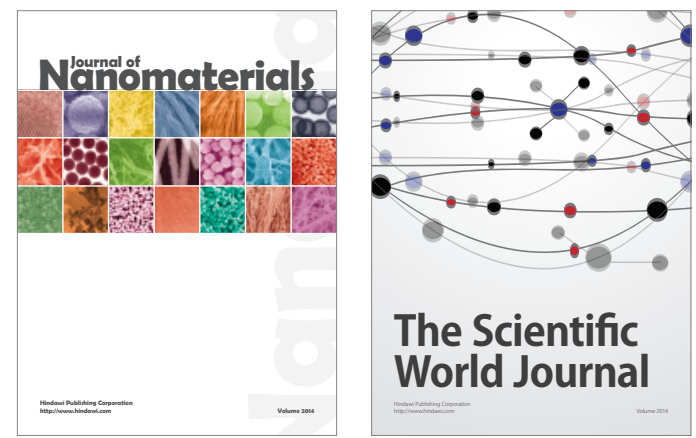

The Scientific World Journal
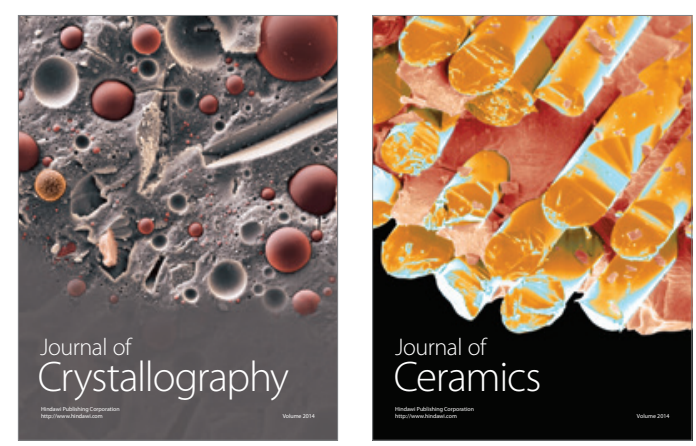
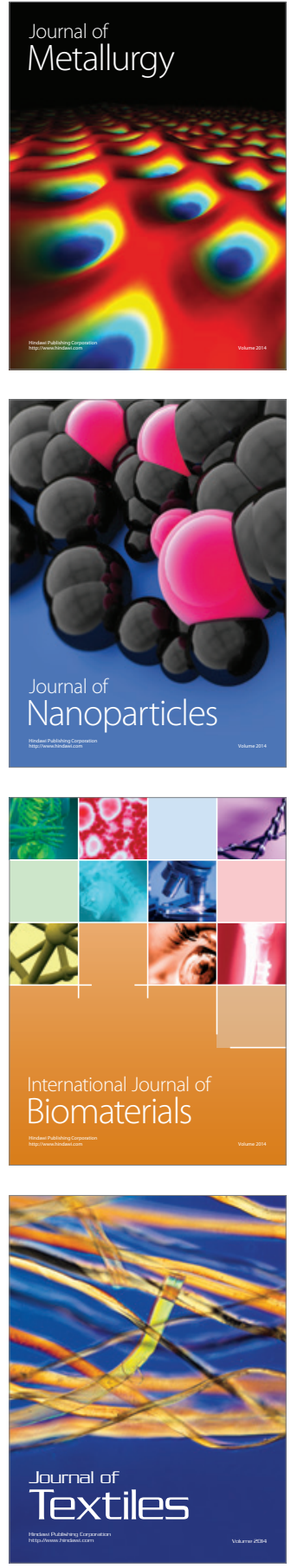